\title{
PENERAPAN MODEL PEMBELAJARAN NUMBER HEADS TOGETHER (NHT) UNTUK MENINGKATKAN HASIL BELAJAR SISWA KELAS VIIA SMP NEGERI 2 TUNTANG PADA MATERI SEGITIGA
}

\author{
Era Destiyandani \\ 202012007@student.uksw.edu \\ Mahasiswa Program Studi S1 Pendidikan Matematika \\ FKIP - Universitas Kristen Satya Wacana \\ Tri Nova Hasti Yunianta \\ trinova.yunianta@staff.uksw.edu \\ Program Studi S1 Pendidikan Matematika \\ FKIP - Universitas Kristen Satya Wacana \\ Helti Lygia Mampouw \\ helti.mampouw@staff.uksw.edu \\ Program Studi S1 Pendidikan Matematika \\ FKIP - Universitas Kristen Satya Wacana
}

\begin{abstract}
ABSTRAK
Penelitian tindakan kelas ini bertujuan untuk meningkatkan hasil belajar dan mendeskripsikan kondisi siswa kelas VIIA SMP Negeri 2 Tuntang pada materi segitiga melalui penerapan model pembelajaran Number Heads Together (NHT). Melalui model pembelajaran NHT, tugas diberikan kepada semua siswa dimana siswa telah diberi nomor berbeda didalam kelompoknya namun masing-masing kelompok menggunakan penomoran yang sama. Pemanggilan nomor siswa secara acak untuk melaporkan hasil diskusi kelompok mendorong setiap siswa secara individu bertanggung jawab atas hasil belajarnya. Instrumen penelitian yang digunakan untuk mengambil data penelitian adalah soal tes dan lembar observasi. Penelitian ini diterapkan pada 31 siswa sebagai subjek dan menggunakan model spiral Kemmis dan McTaggart. Hasil penelitian menunjukkan bahwa persentase ketuntasan siswa untuk materi segitiga tentang mengidentifikasi sifat-sifat segitiga berdasarkan sisi dan sudutnya pada siklus I mencapai $87,1 \%$ tuntas dan ketuntasan meningkat menjadi 96,77\% pada siklus II dengan materi pembelajaran menghitung keliling dan luas segitiga. Hasil ini menunjukkan bahwa penggunaan model pembelajaran NHT telah meningkatkan penguasaan materi segitiga oleh siswa.
\end{abstract}

Kata Kunci: Model Pembelajaran NHT, Hasil Belajar, segitiga

\section{PENDAHULUAN}

Matematika merupakan salah satu pelajaran yang diajarkan pada setiap jenjang pendidikan mulai dari sekolah dasar (SD) sampai dengan sekolah menengah atas (SMA), bahkan perguruan tinggi. Mengingat pentingnya matematika, maka pelajaran matematika yang diberikan kepada siswa harus dipahami siswa karena perannya dibutuhkan dalam kehidupan sehari-hari. Tujuan pembelajaran matematika antara lain agar siswa memahami konsepkonsep matematika, menjelaskan keterkaitan 
antar konsep, mengaplikasikan konsep secara luwes, akurat, efisien, dan tepat serta memiliki sikap menghargai kegunaan matematika dalam kehidupan sehari-hari, yaitu memiliki rasa ingin tahu/kritis, perhatian, dan memiliki rasa percaya diri dalam pemecahan masalah (Depdiknas, 2006). Pelajaran matematika bagi sebagian besar siswa, merupakan pelajaran yang sering dianggap sulit dan membosankan sehingga hasil belajar matematika cenderung kurang baik. Hasil belajar matematika yang cenderung kurang baik ditandai dengan nilai hasil tes evaluasi pelajaran matematika siswa SMP Negeri 2 Tuntang khususnya kelas VIIAmasih rendah.

Berdasarkan hasil wawancara, diperoleh hasil belajar siswa kelas VIIA SMP Negeri 2 Tuntang masih rendah. Hal ini terlihat dari Ulangan Tengah Semester 2 menunjukkan bahwa banyak siswa yang belum mencapai nilai KKM yaitu 70 dengan nilai rata-ratanya adalah 53,23 , dan standar deviasinya adalah 17,14 . Adapun grafik nilai tes pra siklus disajikan pada Gambar 1. Siswa yang sudah mencapai nilai KKM sebanyak 7 siswa (22,58\%), sedangkan siswa yang belum mencapai nilai KKM yang ditetapkan sekolah sebanyak 24 siswa $(77,42 \%)$.
Selain itu, berdasarkan wawancara dan observasi, guru mengatakan bahwa hasil belajar siswa sebelumnya selalu jelek dan siswa masih mengalami kesulitan menyelesaikan masalah geometri, lebih khusus materi segitiga. Materi ini yang akan diajarkan, siswa sering mengalami kesulitan dalam menentukan sisi alas dan tinggi sebuah segitiga, misalnya jika posisi diubah ke posisi yang tidak biasa dilihat oleh siswa dan saat siswa diberikan soal yang berupa soal cerita. Siswa hanya dituliskan rumus luas dan keliling segitiga, sehingga siswa akan lupa dalam menentukan rumus luas dan keliling segitiga. Observasi saat proses pembelajaran menunjukkan beberapa siswa yang merasa takut dengan guru, tidak mendengarkan saat dijelaskan, saat mendapat tugas yang harus dikerjakan siswa cenderung mengerjakan hanya dengan melihat pekerjaan siswa lain, siswa kurang aktif bertanya saat merasa kesulitan, saat maju ke depan hanya siswa yang ingin maju dan siswa merasa bosan. Hal tersebut merupakan penyebab siswa sulit memahami pelajaran yang dijelaskan guru terutama dalam mengerjakan soal-soal. Akibatnya hasil belajar siswa menjadi rendah.

Setiap guru mengharapkan hasil belajar siswanya tidak rendah serta setiap ilmu pengetahuan yang diajarkan dapat dimengerti,

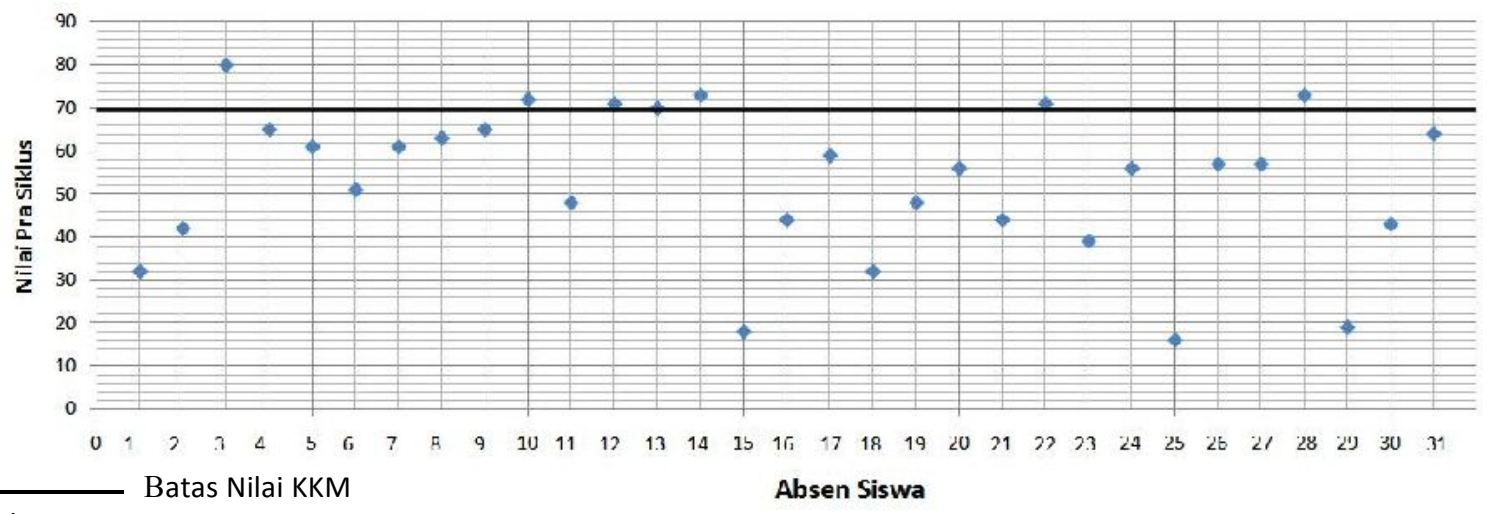

Nilai Rata-rata : 53,23

Standar Deviasi : 17,14

Nilai KKM : 70

Nilai Tertinggi : 80

Nilai Terendah : 16

Gambar 1 Grafik Nilai Tes Pra Siklus 
diterima dan dikuasai oleh siswa dengan baik. Agar harapan setiap guru untuk menuju keberhasilan mengajar tercapai, maka guru harus memiliki kecakapan dan keterampilan dalam menyajikan pelajaran kepada siswa yang dapat menarik atau memfokuskan perhatian siswa. Hal ini dapat dilaksanakan dengan memilih model pembelajaran yang tepat untuk memaksimalkan hasil belajar siswa. Salah satu upaya untuk meningkatkan hasil belajar siswa, yaitu dengan menggunakan model pembelajaran yang membuat siswa fokus dan aktif bertanya saat proses pembelajaran dimana siswa melakukan sebagian pekerjaannya secara individu atau kelompok. Siswa mengeluarkan gagasannya, memecahkan masalah dan dapat menerapkan apa yang siswa pelajari. Belajar yang menyenangkan, mendukung dan menarik hati akan lebih cepat dalam mempelajari sesuatu dengan baik. Salah satu model pembelajaran yang dapat dijadikan sebagai usulan solusi adalah model pembelajaran kooperatif tipe Number Head Together.

Number Head Together (NHT) merupakan salah satu tipe pembelajaran kooperatif yang dapat mendorong siswa aktif dan saling membantu dalam menguasai materi pelajaran untuk mencapai hasil belajar yang maksimal. Pembelajaran NHT diharapkan dapat mengatasi masalah yang dialami siswa kelas VIIA SMP Negeri 2 Tuntang dengan melaksanakan penelitian tindakan kelas (PTK). Menurut penelitian tindakan kelas yang dilakukan oleh Muhammad Fadlan (2013) mengenai Upaya Meningkatkan Hasil Belajar Matematika Siswa Kelas III Min Kebonagung Imogiri Melalui Pembelajaran Kooperatif Tipe Number Heads Together (NHT), hasil penelitian menunjukkan bahwa pembelajaran matematika melalui model kooperatif tipe NHT dapat meningkatkan hasil belajar siswa.
Hasil belajar menurut Sudjana (2009: 22) adalah kemampuan-kemampuan yang dimiliki siswa setelah ia menerima pengalaman belajarnya. Hasil tidak akan pernah dihasilkan selama orang tidak melakukan sesuatu. Sebuah prestasi membutuhkan perjuangan dan pengorbanan yang sangat besar untuk memperoleh hasil. Hanya dengan keuletan, kesungguhan, kemauan yang tinggi dan rasa optimisme diri yang mampu mencapainya.

Berdasarkan paparan di atas, rendahnya hasil belajar siswa pada mata pelajaran matematika menarik untuk ditelusuri. Penelitian ini dilakukan dengan tujuan untuk mengetahui ada tidaknya peningkatan hasil belajar dan mendeskripsikan kondisi siswa kelas VIIA SMP Negeri 2 Tuntang pada materi segitiga melalui penerapan model pembelajaran Number Heads Together (NHT).

\section{HASIL BELAJAR}

Hasil belajar merupakan sebuah kalimat yang terdiri dari dua kata yaitu "hasil" dan "belajar" yang memiliki arti yang berbeda. Rusman (2012: 123) menyatakan hasil belajar adalah sejumlah pengalaman yang diperoleh siswa yang mencakup ranah koqnitif, afektif, dan psikomotorik. Belajar tidak hanya penguasaan konsep teori mata pelajaran saja, tapi juga penguasaan kebiasaan, persepsi, kesenangan, minat-bakat, penyesuaian sosial, macammacam keterampilan, cita-cita, keinginan dan harapan. Agus (2009: 5), hasil belajar adalah pola-pola per-buatan, nilai-nilai, pengertianpengertian, sikap-sikap, apresiasi, dan keterampilan.

Sudjana (2009: 22) menyatakan bahwa hasil belajar adalah kemampuan-kemampuan yang dimiliki siswa setelah ia menerima pengalaman belajarnya. Hasil tidak akan pernah dihasilkan selama orang tidak melakukan sesuatu. Sebuah prestasi membutuhkan 
perjuangan dan pengorbanan yang sangat besar untuk memperoleh hasil. Hanya dengan keuletan, kesungguhan, kemauan yang tinggi dan rasa optimisme diri yang mampu mencapainya. Menurut Arifin (2000) menyatakan bahwa hasil belajar merupakan kemampuan, keterampilan, dan sikap seseorang dalam menyelesaikan suatu hal. Hasil suatu pembelajaran (kemampuan, keterampilan, dan sikap) dapat terwujud jika pembelajaran (kegiatan belajar mengajar) terjadi.

\section{MODEL PEMBELAJARAN NUMBER HEADS TOGETHER (NHT)}

Slavin (2005: 8) menyatakan bahwa dalam model pembelajaran kooperatif, para siswa akan duduk bersama dalam kelompok yang beranggotakan empat orang untuk menguasai materi yang disampaikan oleh guru. Pembelajaran kooperatif merupakan pembelajaran yang mengutamakan adanya kerjasama antar siswa dalam kelompok untuk mencapai tujuan pembelajaran. Siswa dibagi ke dalam kelompok-kelompok kecil dan diarahkan untuk mempelajari materi yang telah ditentukan. Tujuan dibentuknya kelompok kooperatif adalah untuk memberikan kesempatan kepada siswa agar dapat terlibat secara aktif dalam proses berpikir dan dalam kegiatan belajar.

Salah satu tipe model pembelajaran kooperatif adalah NHT. Menurut Lie (2002: 58), pengertian NHT atau kepala bernomor adalah suatu tipe pembelajaran kooperatif yang memberikan kesempatan kepada siswa untuk saling membagikan ide-ide dan mempertimbangkan jawaban yang paling tepat. Selain itu, dapat mendorong siswa untuk meningkatkan semangat kerjasama mereka. Cara seperti ini dapat digunakan dalam semua mata pelajaran dan untuk semua tingkatan usia anak didik.

Sintaks model pembelajaran kooperatif tipe NHT menurut Lie (2002:59) terdiri dari empat langkah. Langkah yang pertama adalah Penomoran (Numbering). Guru mengelompokkan siswa menjadi 8 kelompok yang beranggotakan 3 sampai 4 siswa. Setiap siswa dalam kelompok memiliki nomor yang berbeda. Guru menjelaskan peraturan yang harus dipatuhi siswa. Langkah kedua adalah Pengajuan Pernyataan (Questioning). Guru memberikan pertanyaan yang semua isi pertanyaannya sama kepada masing-masing kelompok. Pertanyaan tersebut diberikan melalui Lembar Kerja Kelompok dan siswa mengerjakannya. Kemudian langkah ketiga adalah Berpikir Bersama (Heads Together). Guru membantu siswa yang merasa kesulitan saat menjawab pertanyaan. Setiap kelompok memutuskan jawaban yang paling benar dengan cara berdiskusi dan anggota kelompok harus mengetahui hasil dari diskusi. Langkah terakhir adalah Pemberian Jawaban (Answering). Guru memanggil salah satu nomor secara acak. Siswa yang nomornya terpanggil diminta untuk melaporkan hasil kerjasama atau diskusi kelompok.

\section{METODE PENELITIAN}

Penelitian ini dilakukan di SMP Negeri 2 Tuntang, dengan subjek penelitian adalah siswa kelas VIIA sebanyak 31 siswa. Jenis penelitian ini adalah penelitian tindakan kelas model spiral yang dikemukakan oleh Kemmis dan Mc Taggart (Wiriaatmadja, 2005), dimana setiap siklus terdiri dari empat tahap yaitu perencanaan, pelaksanaan, observasi, dan refleksi.

Pada tahap perencanaan, ditetapkan cakupan materi segitiga yang berdasarkan Standar Kompetensi tentang memahami konsep segiempat dan segitiga serta menentukan ukurannya pada Kompetensi Dasar tentang (1) mengidentifikasi sifat-sifat segitiga berdasarkan sisi dan sudutnya dan (2) menghitung keliling dan luas segitiga dan segiempat serta meng- 
gunakannya dalam pemecahan masalah. Dirumuskan indikator keberhasilan, membuat lembar kerja kelompok dan membuat pin identitas serta menyusun alat evaluasi berupa tes. Selanjutnya mendesain rencana pelaksanaan pembelajaran yang mengikuti standar proses sesuai Permendiknas No.41 tahun 2007.

Pada tahap pelaksanaan, pembelajaran dilaksanakan sesuai dengan rencana. Proses pembelajaran yang menggunakan pembelajaran NHT mengarah pada pencapaian indikator keberhasilan belajar siswa. Selama proses pembelajaran berlangsung, guru sebagai peneliti melakukan pengamatan aktivitas kegiatan siswa. Kegiatan belajar siswa dipantau dan setiap akhir siklus dilakukan tes tertulis. Tahap refleksi dilaksanakan pada akhir siklus. Hasil dari pengamatan dan tes tertulis digunakan sebagai masukkan pada rencana tindakan selanjutnya.

Penelitian ini terdiri dari 2 siklus, masingmasing siklus menggunakan model pembelajaran NHT. Ditetapkan kriteria keberhasilan siklus yaitu memenuhi kriteria ketuntasan belajar secara kelas minimum (KKM) 75\%, di mana siswa disebut tuntas secara individu apabila mencapai nilai 70. Apabila terdapat siklus yang tidak memenuhi kriteria keberhasilan siklus, maka siklus tersebut dilanjutkan siklus berikutnya lagi.

Teknik pengumpulan data dalam penelitian ini menggunakan tes dan lembar observasi. Kemudian teknik analisis data penelitian ini adalah dengan menggunakan tes yang dilakukan setiap akhir siklus, dimana tes digunakan untuk mengukur kemampuan siswa dalam ranah kognitif. Data yang sudah dikumpulkan, maka dianalisis menggunakan analisis membandingkan antar siklus yaitu pra siklus, siklus I, dan siklus II.

\section{HASIL DAN PEMBAHASAN}

\section{Kondisi pra siklus}

Pada tes ulangan tengah semester 2 , nilai tes pra siklus menunjukkan hasil yang kurang baik. Nilai tes pra siklus dapat dilihat pada Tabel 1. Hasil belajar tersebut menunjukkan bahwa pembelajaran perlu diperbaiki. Penggunaan pembelajaran NHT diharapkan dapat meningkatkan hasil belajar siswa.

Tabel 1 Distribusi Frekuensi Nilai Tes Pra Siklus

\begin{tabular}{ccc}
\hline Nilai & Frekuensi & $\begin{array}{c}\text { Persentase } \\
(\%)\end{array}$ \\
\hline $89-80$ & 1 & 3,2 \\
$79-70$ & 6 & 19,36 \\
$69-60$ & 6 & 19,36 \\
$59-50$ & 6 & 19,36 \\
$49-40$ & 6 & 19,36 \\
$<40$ & 6 & 19,36 \\
\hline Jumlah & 31 & 100 \\
\hline
\end{tabular}

\section{Deskripsi siklus I}

Siklus I dilaksanakan pada tanggal 16 sampai 20 Mei 2016. Rumusan indikator adalah

a. Menentukan jenis-jenis segitiga berdasarkan sisi-sisinya

b. Menentukan jenis-jenis segitiga berdasarkan besar sudutnya

c. Menentukan besar salah satu sudut segitiga apabila dua sudut lainnya diketahui

Media pembelajaran yang digunakan adalah pin identitas, lembar kerja kelompok dan papan pelanggaran.

\section{Perencanaan Tindakan}

Pada tahap ini dilakukan hal-hal sebagai berikut: (1) mempelajari materi yang ditetapkan bersama dengan guru yaitu materi segitiga, (2) membuat pin identitas, (3) membuat lembar kerja kelompok yang ditetapkan bersama dengan guru, (4) membuat papan pelanggaran, 
a

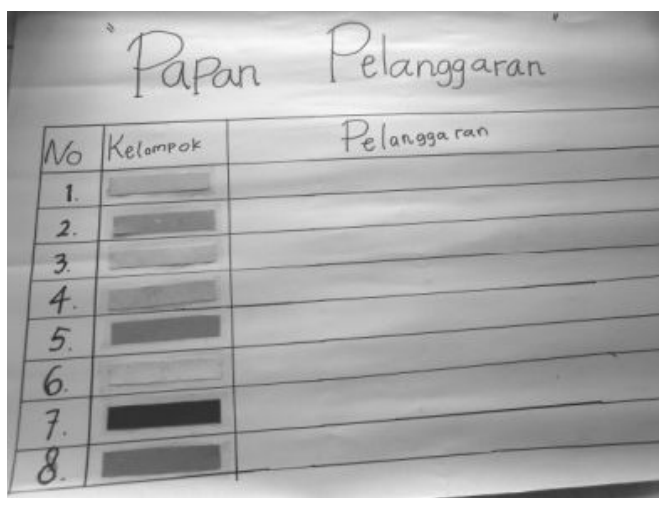

b

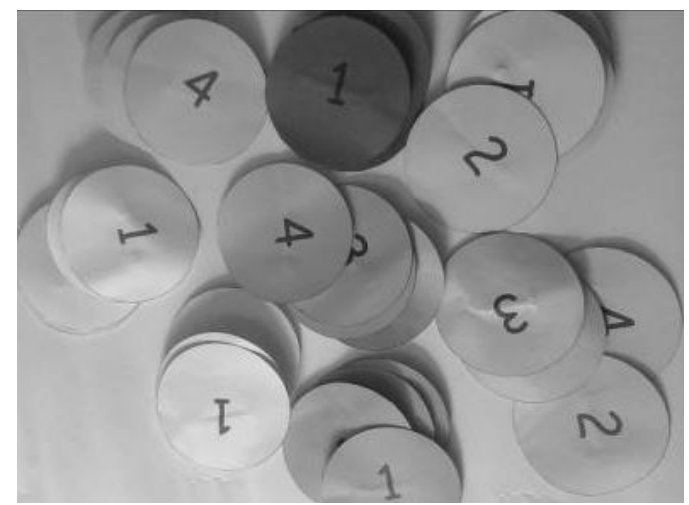

Gambar 2 Media Pembelajaran : (a) Papan Pelanggaran dan (b) Pin Identitas

(5) menyusun rencana pelaksanaan pembelajaran (RPP) dan (6) membuat soal evaluasi beserta dengan kunci jawaban.

\section{b. Pelaksanaan Pembelajaran}

\section{Pertemuan Pertama}

1) Pendahuluan

Pelaksanaan pembelajaran dimulai dengan memberikan salam dan mengabsen kehadiran siswa. Guru mengingatkan siswa dengan materi sebelumnya yaitu garis dan sudut yang akan digunakan pada bangun segitiga. Dua buah garis lurus yang membentuk sebuah sudut apabila dipotong oleh garis lain akan memiliki tiga buah sudut dan ketiga garis tersebut dapat disebut dengan sisi. Ketiga buah sisi dan ketiga buah sudut tersebut membatasi sebuah bangun datar yaitu bangun datar segitiga.

2) Kegiatan Inti

Kegiatan inti dilakukan sesuai dengan sintaks model pembelajaran NHT sebagai berikut: guru mengelompokkan siswa kedalam 8 kelompok yang terdiri dari 3 sampai 4 siswa. Setiap siswa dalam kelompok mendapat pin identitas yang berbeda dan diharuskan untuk menggunakan. Guru menjelaskan peraturan yang harus dipatuhi.
Guru memberikan soal yang isinya sama semua kepada masing-maing kelompok. Soal tersebut diberikan melalui Lembar Kerja Kelompok sebanyak 3 buah soal dengan materi jenis-jenis segitiga dan siswa mengerjakannya. Secara bersama-sama dengan anggota kelompoknya siswa mengerjakan soal tersebut.

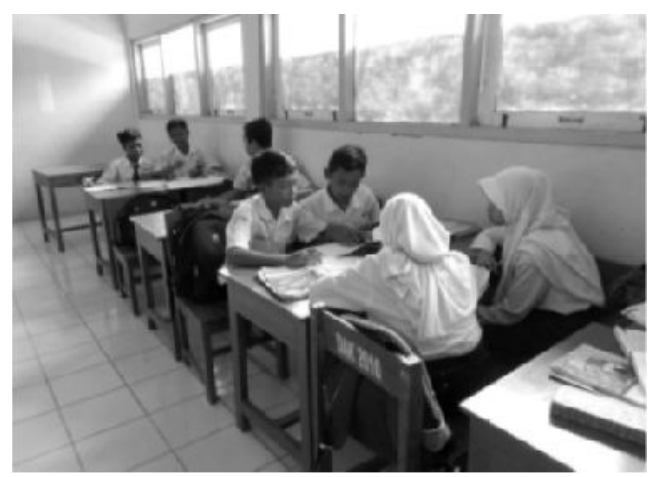

Gambar 3 Diskusi Kelompok

Siswa diberikan waktu untuk berdiskusi. Setelah semua kelompok selesai mengerjakan, guru memanggil salah satu nomor secara acak. Siswa yang nomornya terpanggil diminta untuk mengerjakan di depan tanpa menggunakan jawaban dan hanya melihat lembar soal. Guru mengoreksi jawaban siswa dan menuliskan skor yang didapat.

Selama berdiskusi, tampak ada beberapa siswa yang tidak mengemukakan pendapatnya dan ada siswa yang membicarakan hal lain yang tidak berhubungan dengan soal yang telah 
diberikan oleh guru. Siswa yang tidak ikut serta dalam berdiskusi dan hanya bergantung dengan temannya, saat nomornya terpanggil maju ke depan merasa kesulitan dan menjawab soal tersebut dengan salah.

\section{1) Kegiatan Penutup}

Sebelum mengakhiri pelajaran, guru dan siswa mendiskusikan soal yang masih belum dipahami oleh siswa dan menjelaskan kepada siswa yang memiliki pemahaman yang keliru. Guru memberikan pekerjaan rumah untuk materi selanjutnya.

\section{Pertemuan Kedua}

1) Pendahuluan

Kegiatan awal dimulai denganmemberikan salam dan mengabsen kehadiran siswa. Guru mengingatkan siswa dengan materi sebelumnya yaitu menentukan jenis segitiga berdasarkan panjang sisinya dan besar sudutnya. Siswa diberi pertanyaan "jika segitiga ketiga sisinya sama panjang. Tentukan jenis segitiga tersebut!'. Guru menyampaikan tujuan pembelajaran yakni belajar tentang jumlah sudut-sudut segitiga.

2) Kegiatan Inti

Kegiatan inti dilakukan sesuai dengan sintaks model pembelajaran NHT sebagai berikut: guru mengelompokkan siswa ke dalam 8 kelompok yang terdiri dari 3 sampai 4 siswa. Setiap siswa dalam kelompok mendapat pin identitas yang berbeda dan diharuskan untuk menggunakan. Gurumenjelaskan peraturan yang harus dipatuhi.

Guru memberikan soal yang isinya sama semua kepada masing-maing kelompok. Soal tersebut diberikan melalui Lembar Kerja Kelompok sebanyak 2 buah soal dengan materi jumlah sudut-sudut segitiga dan siswa mengerjakannya. Secara bersama-sama dengan anggota kelompoknya siswa mengerjakan soal tersebut.
Siswa diberikan waktu untuk berdiskusi. Setelah semua kelompok selesai mengerjakan, guru memanggil salah satu nomor secara acak. Siswa yang nomornya terpanggil diminta untuk mengerjakan didepan tanpa menggunakan jawaban dan hanya melihat lembar soal. Selama berdiskusi, tidak seperti pada pertemuan pertama karena tampak siswa yang ikut dalam memberikan pendapatnya dalam mengerjakan soal tersebut sudah banyak, namun masih ada siswa yang membicarakan hal lain yang tidak berhubungan dengan soal yang telah diberikan oleh guru. Saat mendapat giliran maju ke depan untuk mempresentasikan apa yang telah dikerjakan bersama kelompoknya sudah mengalami kemajuan kebanyakan siswa yang maju hampir seluruhnya menjawab dengan benar.

3) Kegiatan Penutup

Sebelum mengakhiri pelajaran, guru dan siswa mendiskusikan soal yang masih belum dipahami oleh siswa dan menjelaskan kepada siswa yang memiliki pemahaman yang keliru. Guru dan siswa menyimpulkan bersama.

\section{Pertemuan Ketiga}

Pertemuan ketiga, guru memberikan soal tes dan siswa diminta untuk mengerjakan secara individu. Semua buku di tutup dan tidak boleh bertanya dengan teman lainnya. Setelah selesai mengerjakan dibahas bersama soal yang terasa sulit.

a. Hasil Observasi

Hasil observasi selama proses pembelajaran berlangsung adalah pada pertemuan pertama masih terlihat siswa yang pasif saat berdiskusi. Siswa yang bergurau dan membahas hal lain masih banyak. Sebagian siswa tidak mendengarkan dan mencatat yang dijelaskan guru. Beberapa siswa tidak mengerjakan soal latihan yang diberikan oleh guru. Pada pertemuan kedua, siswa yang bergurau dan membahas hal 
lain hanya sebagian saja tidak seperti pertemuan pertama. Sebagian siswa tidak mengerjakan lembar kerja kelompok yang diberikan. Seluruh siswa mulai mendengarkan dan mencatat yang dijelaskan guru.

Soal tes tertulis terdiri dari 3 nomor di mana jika jawabannya benar soal nomor 1 diberi skor 30, nomor 2 diberi skor 20 dan nomor 3 diberi skor 50. Pada siklus I beberapa

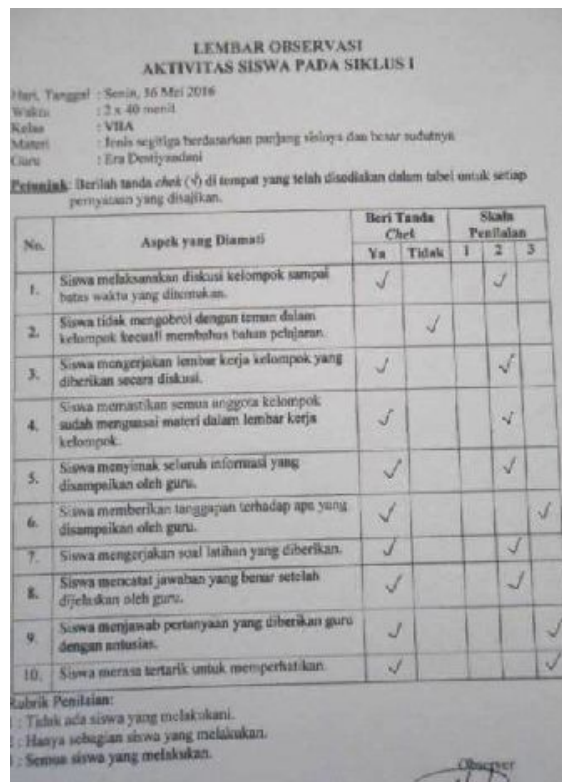

Gambar 4 Lembar Observasi Aktivitas Siswa Pertemuan Pertama Siklus I siswa sudah mencapai nilai KKM yaitu 70 dengan nilai rata-ratanya adalah 76,55 , dan standar deviasinya adalah 7,83. Adapun grafik nilai tes siklus I disajikan pada Gambar 6 .

Siswa yang sudah mencapai nilai KKM sebanyak 27 siswa (87,1\%), sedangkan siswa yang belum mencapai nilai KKM yang ditetapkan sekolah sebanyak 4 siswa (12,90\%). Nilai tes siklus I dapat dilihat pada Tabel 2.

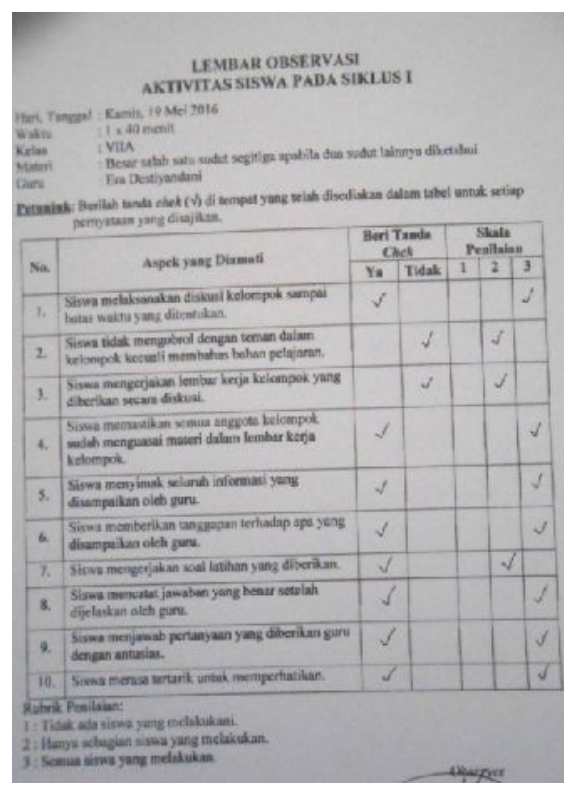

Gambar 5 Lembar Observasi Aktivitas Siswa Pertemuan Kedua Siklus I

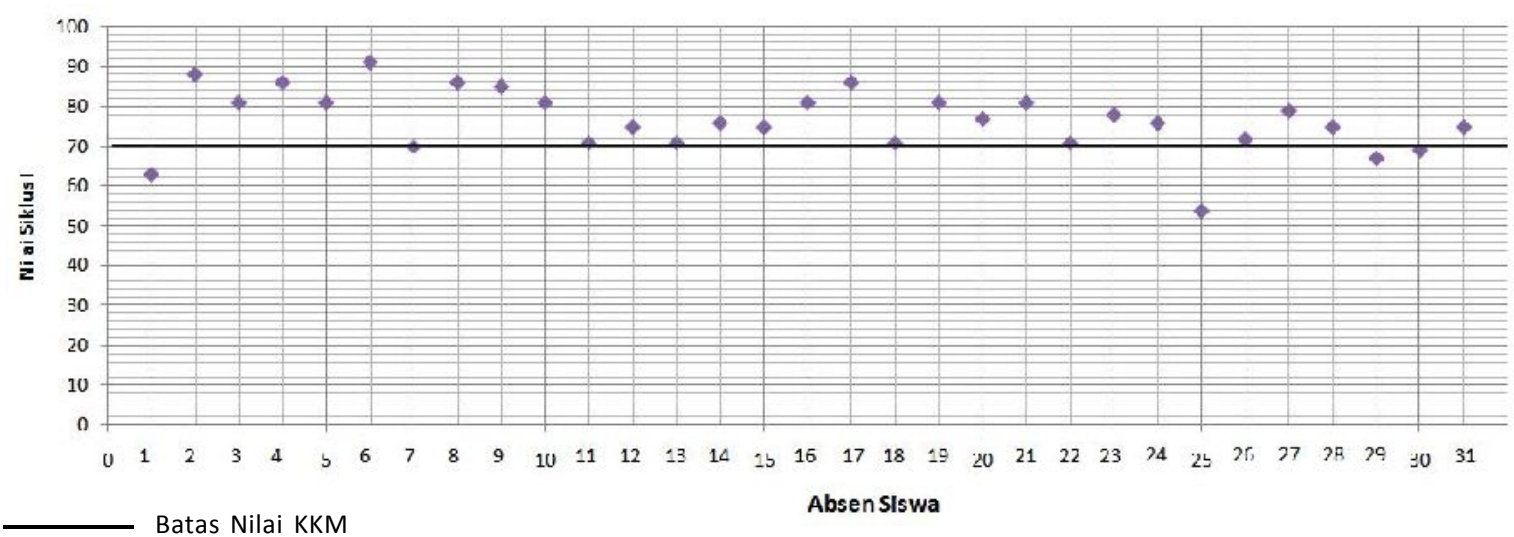

Nilai Rata-rata : 76,55

Standar Deviasi : 7,83

Nilai KKM $: 70$

Nilai Tertinggi : 91

Nilai Terendah : 54

Gambar 6 Grafik Nilai Tes Siklus I 
Tabel 2 Distribusi Frekuensi Nilai Tes Siklus I

\begin{tabular}{ccc}
\hline Nilai & Frekuensi & $\begin{array}{c}\text { Persentase } \\
(\%)\end{array}$ \\
\hline $100-90$ & 1 & 3,23 \\
$89-80$ & 11 & 35,48 \\
$79-70$ & 15 & 48,38 \\
$69-60$ & 3 & 9,68 \\
$59-50$ & 1 & 3,23 \\
$<50$ & - & - \\
\hline Jumlah & 31 & 100 \\
\hline
\end{tabular}

b. Refleksi

Berdasarkan pengamatan pada saat pembelajaran dan capaian hasil tes tertulis nampak bahwa terdapat kelebihan dan kekurangan dalam pembelajaran.

Kelebihan meliputi:

1) Pengelompokkan siswa yang ditetapkan dan memberikan nama kelompok dengan nama warna oleh guru membuat beberapa siswa merasa senang dan tertarik mengikuti proses pembelajaran.

2) Hasil tes tertulis siswa menunjukkan pencapaian yang baik. Meskipun dalam proses pembelajaran masih beberapa siswa yang suka bergurau.

3) Pelaksanaan pembelajaran telah berpusat pada siswa.

Kelemahan meliputi:

1) Cara mengoreksi jawaban siswa yang maju ke depan kurang efisien.

2) Pengelolaan siswa pada saat berkelompok belum baik. Pada saat berkelompok siswa tidak terlihat sedang berkelompok karena tempat duduk antar kelompok tidak ada jarak.

3) Siswa yang pasif saat berdiskusi masih terlihat banyak.

\section{Deskripsi siklus II}

Siklus II dilaksanakan pada tanggal 23 sampai 27 Mei 2016. Rumusan indikator adalah

a. Menentukan keliling bangun segitiga.

b. Menentukan luas bangun segitiga.

Media pembelajaran yang digunakan seperti pada siklus I yaitu pin identitas, lembar kerja kelompok dan papan pelanggaran.

a. Perencanaan Tindakan

Pada tahap ini dilakukan hal-hal sebagai berikut: (1) menyiapkan pin identitas, (2) membuat lembar kerja kelompok, (3) menyiapkan papan pelanggaran, (4) menyusun rencana pelaksanaan pembelajaran (RPP) dan (5) membuat soal evaluasi beserta dengan kunci jawaban.

b. Pelaksanaan Pembelajaran

Pertemuan Pertama

1) Pendahuluan

Kegiatan awal dimulai denganmemberikan salam dan mengabsen kehadiran siswa. Siswa telah duduk sesuai dengan kelompoknya dan menggunakan pin identitas. Guru mengingatkan siswa dengan materi sebelumnya yaitu dengan memberikan soal di papan tulis "tentukan nilai $x^{\circ}$ pada $\triangle \mathrm{ABC}$ dengan

$$
\angle A=60^{\circ}, \angle B=x^{\circ} \text { dan } \angle C=x^{\circ} \text { !" }
$$

Guru meminta salah satu siswa untuk maju dan menyelesaikannya. Guru menyampaikan tujuan pembelajaran yakni belajar tentang keliling segitiga.

\section{2) Kegiatan Inti}

Kegiatan inti dilakukan sesuai dengan sintaks model pembelajaran NHT yaitu berkelompok seperti saat pertemuan sebelumnya pada siklus I. Pin identitas dan peraturan yang masih sama. Guru memberikan soal yang isinya sama semua kepada masing-maing kelompok. Soal tersebut diberikan melalui Lembar Kerja Kelompok sebanyak 3 buah soal dengan materi keliling segitiga dan siswa mengerjakannya. 
Secara bersama-sama dengan anggota kelompoknya siswa mengerjakan soal tersebut.

Siswa diberikan waktu untuk berdiskusi Setelah semua kelompok selesai mengerjakan, guru memanggil salah satu nomor secara acak. Siswa yang nomornya terpanggil diminta untuk mengerjakan di depan tanpa menggunakan jawaban dan hanya melihat lembar soal. Guru mengoreksi jawaban siswa dan menuliskan skor yang didapat.

Selama berdiskusi, guru menegur siswa yang tidak ikut berdiskusi dan tidak fokus dalam mengerjakan soal. Siswa yang pada pertemuan sebelumnya yang tidak fokus dalam mengerjakan soal menjadi fokus mengerjakan soal dan tidak membicarakan hal lain lagi selain soal yang diberikan. Saat mendapat giliran maju ke depan untuk mempresentasikan hasil diskusi dengan anggota kelompoknya, seluruh siswa tidak merasa kesulitan. Selain itu, sudah tidak ada siswa yang berbuat curang saat mengerjakan di depan kelas.

\section{3) Kegiatan Penutup}

Sebelum mengakhiri pelajaran, guru memberikan penjelasan yang belum siswa mengerti dan meminta siswa untuk menyimpul-kan apa yang telah dipelajari pada pertemuan tersebut. Kemudian guru memberikan latihan soal untuk dikerjakan di rumah dan memberikan 2 buah soal sebagai quiz yang harus dikerjakan di kelas.

\section{Pertemuan Kedua}

\section{1) Pendahuluan}

Kegiatan awal diawali dengan guru mengucapkan salam, mengabsen siswa, memberikan apersepsi yaitu dengan pertanyaan "tolong tuliskan rumus keliling segitiga!”. Guru meminta 3 siswa untuk menuliskan di papan tulis. Selain itu, guru menyampaikan tujuan pembelajaran yang akan dicapai yaitu belajar tentang luas segitiga.
2) Kegiatan Inti

Kegiatan inti dilakukan sesuai dengan sintaks model pembelajaran NHT yaitu berkelompok seperti saat pertemuan pertama. Pin identitas dan peraturan yang masih sama. Guru memberikan soal yang isinya sama semua kepada masing-maing kelompok. Soal tersebut diberikan melalui Lembar Kerja Kelompok sebanyak 2 buah soal dengan materi luas segitiga dan siswa mengerjakannya. Secara bersama-sama dengan anggota kelompoknya siswa mengerjakan soal tersebut.

Siswa diberikan waktu untuk berdiskusi. Setelah semua kelompok selesai mengerjakan, guru memanggil salah satu nomor secara acak. Siswa yang nomornya terpanggil diminta untuk mengerjakan di depan tanpa menggunakan jawaban dan hanya melihat lembar soal. Guru mengoreksi jawaban siswa dan menuliskan skor yang didapat.

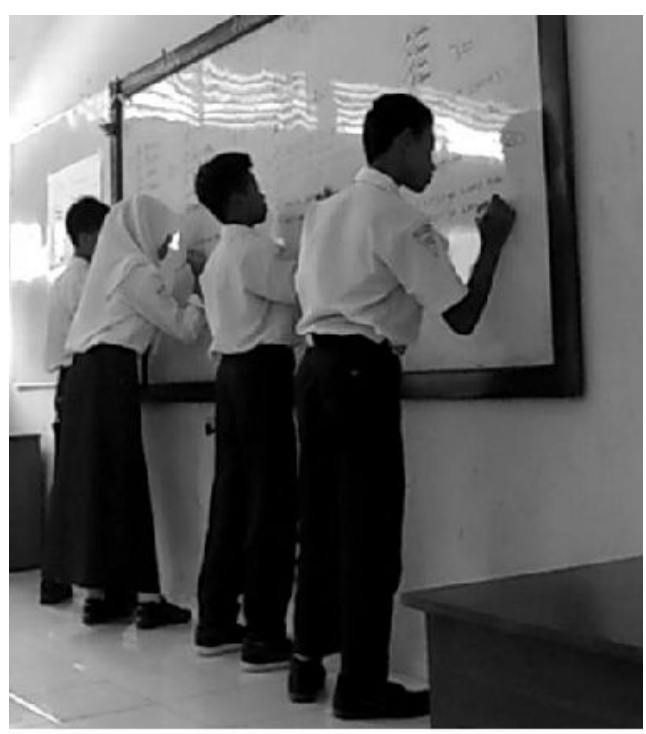

Gambar 7 Siswa Mengerjakan di Depan Kelas

Pertemuan kedua ini, nampak banyak kemajuan karena hampir semua siswa dengan antusias mengerjakan soal yang diberikan dan berdiskusi dengan anggota kelompok lainnya. Semua siswa berusaha fokus dalam kelompoknya masing-masing. Saat mendapat giliran maju 
ke depan untuk mempresentasikan hasil diskusinya siswa sudah tidak ragu-ragu lagi.

\section{3) Kegiatan Penutup}

Sebelum mengakhiri pelajaran, guru memberikan kesempatan kepada siswa untuk bertanya materi yang belum dipahami. Guru memberikan latihan soal yang harus dikerjakan di rumah dan memberikan 2 buah soal sebagai soal quiz yang harus dikerjakan di kelas.

\section{Pertemuan Ketiga}

Pertemuan ketiga, guru memberikan soal tes dan siswa diminta untuk mengerjakan secara individu. Semua buku di tutup dan tidak boleh bertanya dengan teman lainnya. Setelah selesai mengerjakan dibahas bersama soal yang terasa sulit.

\section{a. Hasil Observasi}

Hasil observasi selama proses pembelajaran berlangsung adalah pada pertemuan pertama masih terlihat siswa yang pasif saat berdiskusi. Siswa yang bergurau dan membahas hal lain masih banyak. Sebagian siswa tidak mendengarkan dan mencatat yang dijelaskan guru. Beberapa siswa tidak mengerjakan soal latihan yang diberikan oleh guru. Pada pertemuan kedua, menunjukkan bahwa seluruh siswa sudah terlibat dalam proses pembelajaran, tidak hanya sebagian siswa yang mengikuti. Semua siswa melaksanakan diskusi kelompok sampai selesai, tidak mengobrol dengan teman dalam kelompok kecuali membahas soal, mengerjakan lembar kelompok secara diskusi, memastikan semua anggota kelompok sudah menguasai materi dalam lembar kerja kelompok, menyimak seluruh informasi yang disampaikan oleh guru, memberikan tanggapan terhadap apa yang disampaikan oleh guru, mengerjakan latihan soal, mencatat jawaban yang benar setelah dijelaskan oleh guru, menjawab pertanyaan yang diberikan guru dengan antusias, dan siswa merasa tertarik untuk memperhatikan.

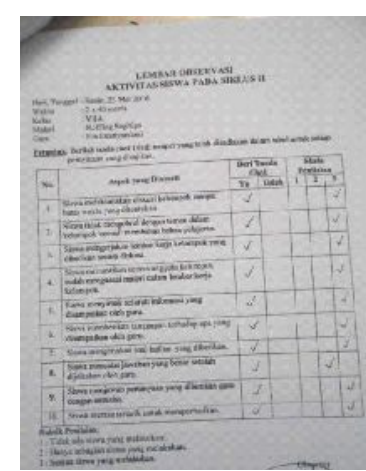

Gambar 8 Lembar Observasi Pertama Siklus II Aktivitas Siswa Pertemuan

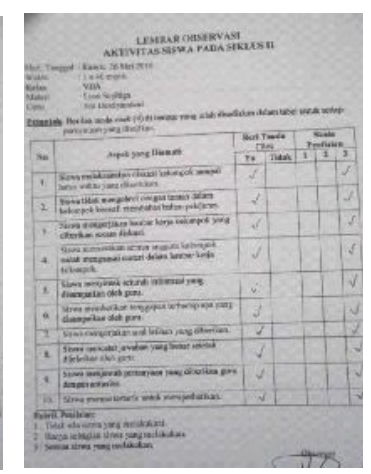

Gambar 9 Lembar Observasi Aktivitas Siswa Pertemuan Kedua Siklus II
Soal tes tertulis terdiri dari 3 nomor di mana jika jawabannya benar soal nomor 1 diberi skor 30, nomor 2 diberi skor 30 dan nomor 3 diberi skor 40. Pada siklus II banyak siswa yang sudah mencapai nilai KKM yaitu 70 dengan nilai rata-ratanya adalah 89,1 , dan standar deviasinya adalah 7,56. Adapun grafik nilai tes siklus I disajikan pada Gambar 10.

Siswa yang sudah mencapai nilai KKM sebanyak 30 siswa $(96,77 \%)$, sedangkan siswa yang belum mencapai nilai KKM yang ditetapkan sekolah sebanyak 1 siswa (3,23\%). Nilai tes siklus II dapat dilihat pada Tabel 3.

Tabel 3 Distribusi Frekuensi Nilai Tes Siklus II

\begin{tabular}{ccc}
\hline Nilai & Frekuensi & $\begin{array}{c}\text { Persentase } \\
(\%)\end{array}$ \\
\hline $100-90$ & 18 & 58,06 \\
$89-80$ & 10 & 32,26 \\
$79-70$ & 2 & 6,45 \\
$69-60$ & 1 & 3,23 \\
$<60$ & - & - \\
\hline Jumlah & 31 & 100 \\
\hline
\end{tabular}

\section{b. Refleksi}

Berdasarkan pengamatan pada saat pembelajaran dan capaian hasil tes tertulis diperoleh bahwa:

1) Hasil belajar siswa telah tuntas.

2) Siswa menujukkan rasa antusias saat proses pembelajaran. 
3) Penguasaan materi segitiga telah dikuasai siswa.

4) Berhasilnya proses pembelajaran menggunakan pembelajaran NHT.

\section{Deskripsi Antar Siklus}

Perbandingan hasil pra siklus, siklus I dan siklus II disajikan dalam Tabel 4.

Dibandingkan dengan siklus I, hasil belajar pada siklus II mengalami kenaikan. Siswa yang tuntas meningkat sebesar $9.67 \%$. Membandingkan Tabel 2 dan Tabel 3, ratarata nilai tes siswa naik dari 76,55 pada siklus I menjadi 89,1 pada siklus II. Adapun grafik peningkatan nilai tes setiap siswa antar siklus disajikan dalam Gambar 11.

Hasil observasi yang dilaksanakan pada siklus I dan siklus II menunjukkan bahwa pada siklus Isiswa belum terbiasa menggunakan model pembelajaran NHT, sedangkan pada siklus II siswa terbiasa dengan menggunakan model pembelajaran NHT. Pada siklus I masih terlihat beberapa siswa yang pasif saat berdiskusi. Siswa yang bergurau dan membahas hal lain masih banyak. Beberapa siswa tidak mengerjakan soal latihan yang diberikan oleh guru. Pada siklus II, seluruh siswa sudah terlibat dalam proses pembelajaran, tidak hanya sebagian siswa yang mengikuti. Semua siswa melaksanakan diskusi kelompok sampai selesai, tidak mengobrol dengan teman dalam kelompok kecuali membahas soal, mengerjakan lembar kelompok secara diskusi, memastikan semua anggota kelompok sudah menguasai materi dalam lembar kerja kelompok, menyimak seluruh informasi yang disampaikan oleh guru, memberikan tanggapan terhadap apa

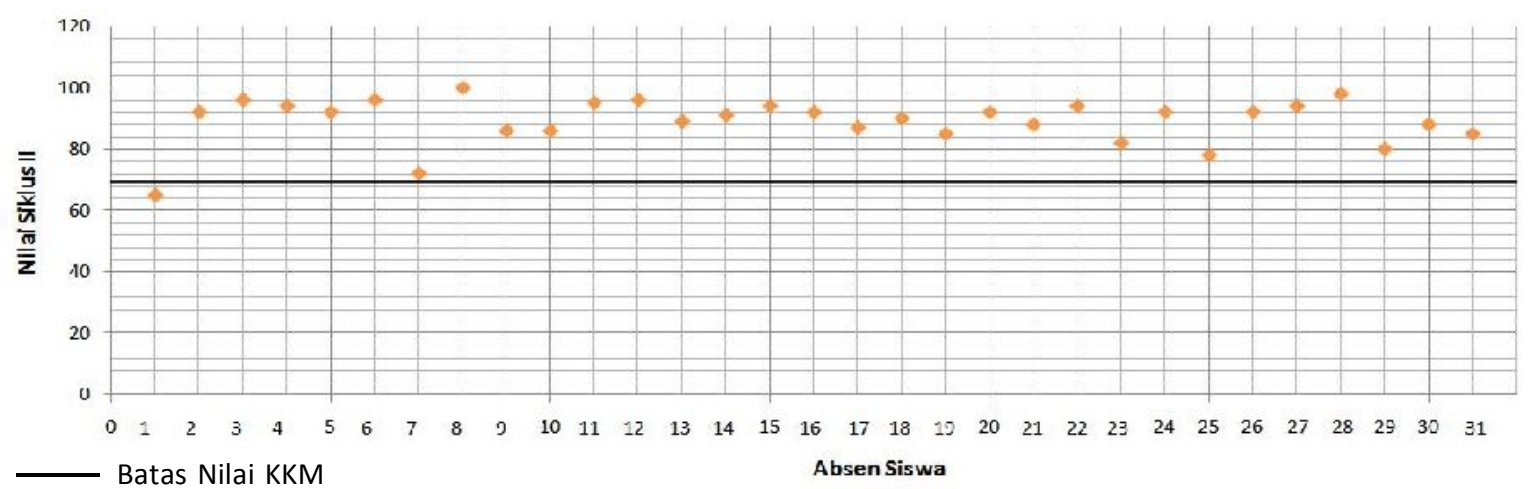

Nilai Rata-rata : 89,1

Standar Deviasi : 7,56

Nilai KKM : :70

Nilai Tertinggi : 100

Nilai Terendah : 65

Gambar 10 Grafik Nilai Tes Siklus II

Tabel 4 Perbandingan Hasil Pra Siklus, Siklus I dan Siklus II

\begin{tabular}{cccccccc}
\hline \multirow{2}{*}{ Nilai } & \multicolumn{2}{c}{ Pra Siklus } & \multicolumn{2}{c}{ Siklus I } & \multicolumn{2}{c}{ Siklus II } & \multirow{2}{*}{ Keterangan } \\
\cline { 2 - 6 } & f & $\mathbf{\%}$ & f & \% & f & \% & \\
\hline $100-90$ & - & - & 1 & 3,23 & 18 & 58,06 & Tuntas \\
$89-80$ & 1 & 3,2 & 11 & 35,48 & 10 & 32,26 & \\
$79-70$ & 6 & 19,36 & 15 & 48,38 & 2 & 6,45 & \\
$69-60$ & 6 & 19,36 & 3 & 9,68 & 1 & 3,23 & \\
$59-50$ & 6 & 16,36 & 1 & 3,23 & - & - & Tidak Tuntas \\
$49-40$ & 6 & 19,36 & - & - & - & - & \\
$<40$ & 6 & 19,36 & - & - & - & - & \\
\hline Jumlah & 31 & 100 & 31 & 100 & 31 & 100 & \\
\hline
\end{tabular}


yang disampaikan oleh guru, mengerjakan latihan soal, mencatat jawaban yang benar setelah dijelaskan oleh guru, menjawab pertanyaan yang diberikan guru dengan antusias, dan siswa merasa tertarik untuk memperhatikan. Setelah menerapkan model pembelajaran NHT, saat berdiskusi siswa lebih aktif dalam mengemukakan pendapatnya, siswa lebih siap saat dipanggil guru untuk mempresentasikan hasil diskusi kelompok dan siswa menjadi lebih saling membantu atau bekerjasama dengan anggota kelompoknya.

Berdasarkan penelitian yang telah dilakukan ini, secara umum siswa dapat mengikuti pembelajaran dengan baik karena terlihat antusias dan bisa mengikuti apa yang diinstruksikan guru, serta merasa senang karena terlibat langsung dalam proses pembelajaran, aktif dalam bertanya, memberikan tanggapan, dan maju ke depan untuk mengerjakan soal. Selain itu, siswa dengan percaya diri memberikan ide atau gagasannya untuk menyelesaikan soal. Peneliti menyadaribahwaadanyakekurangan-kekurangan selama proses pembelajaran sehingga pada pertemuan selanjutnya peneliti lebih mengoptimalkan dalam mengarahkan dan mem- bimbing siswa agar hasil belajar siswa juga jauh lebih baik seperti yang diharapkan.

\section{PENUTUP}

Berdasarkan hasil penelitian dan pembahasannya dapat disimpulkan bahwa model pembelajaran NHT dapat meningkatkan hasil belajar siswa. Hal ini dapat terjadi karena pada saat proses pembelajaran dengan menggunakan model pembelajaran NHT siswa terlihat antusias dan merasa tidak bosan saat diberikan soal. Secara tidak sadar siswa telah melakukan beberapa perekaman informasi secara berkala yaitu saat melakukan diskusi dengan anggota kelompoknya, maju ke depan untuk mengerjakan soal mewakili kelompoknya tanpa menggunakan jawaban, dan saat mencatat. Kondisi seperti itulah yang membuat siswa lebih aktifdan kritis dalam pembelajaran sehingga proses pembelajaran berjalan dengan baik dan akibatnya hasil belajarnya juga baik. Hasil pra siklus menunjukkan ketuntasan klasikal 22,58\%, pada siklus I sebesar 87,1\% dan pada siklus II sebesar $96,77 \%$.

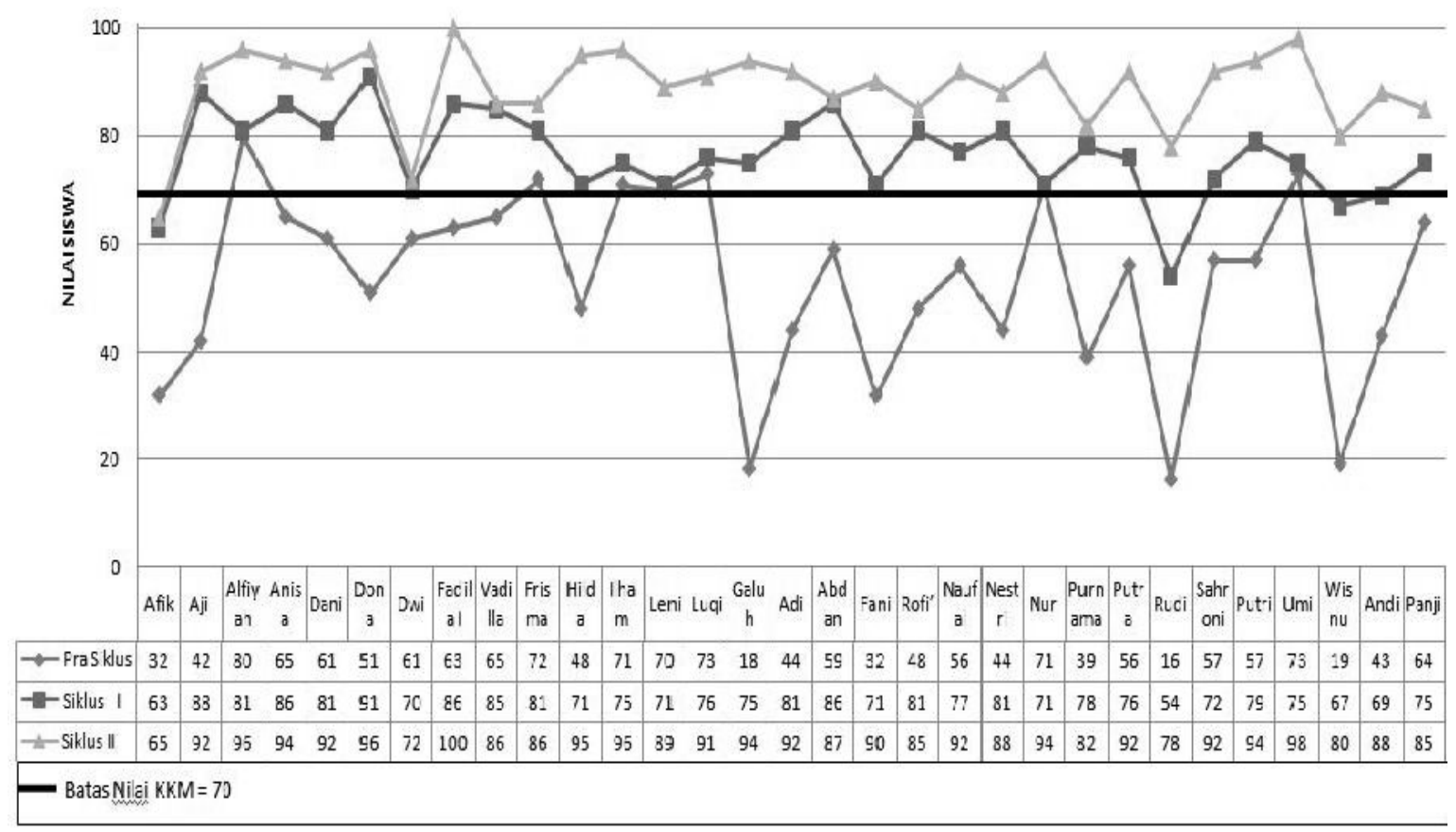

Gambar 11 Grafik Nilai Setiap Siswa Antar Siklus 
Berdasarkan kesimpulan di atas, untuk dapat mengoptimalkan model pembelajaran NHT dapat diberikan saran yaitu model pembelajaran NHT dapat dijadikan sebagai salah satu alternatif dalam pembelajaran matematika untuk meningkatkan hasil belajar siswa dan dapat digunakan untuk mata pelajaran yang lainnya. Hendaknya guru memberikan bimbingan khusus seperti jam pelajaran tambahan kepada siswa yang belum mencapai KKM yaitu 70 . Pada saat proses pembelajaran matematika yang menerapakan model pembelajaran NHT hendaknya siswa dapat lebih aktif bertanya dan bekerjasama saat berdiskusi sehingga hasil belajarnya pun dapat maksimal. Siswa yang belum mencapai KKM sebaiknya belajar lebih giat lagi. Sebaiknya kepala sekolah selalu memberi dorongan kepada guru untuk aktif mengembangkan model pembelajaran yang lebih efektif dan menarik untuk siswa. Selain itu, memotivasi dan memfasilitasi rekan guru untuk menggunakan model pembelajaran NHT baik pada kelas VII, kelas VIII maupun kelas IX pada mata pelajaran Matematika dan mata pelajaran lain.

\section{DAFTAR PUSTAKA}

Depdiknas. 2006. Kurikulum Tingkat Satuan Pendidikan (KTSP) 2006 Mata Pelajaran Matematika. Jakarta: Departemen Pendidikan Nasional.
Depdiknas, Permendiknas No.41 tahun 2007, tentang Standar Proses.

Fadlan, Muhammad. 2013. Upaya Meningkatkan Hasil Belajar Matematika Siswa Kelas III Min Kebonagung Imogiri Melalui Pembelajaran Kooperatif Tipe Number Heads Together (NHT). Skripsi. UIN SUNAN KALIJAGA. http:// digilib.uin-suka.ac.id/9160 diakses 10 Juni 2016.

Kunandar. 2011. Langkah Mudah Penelitian Tindakan Kelas Sebagai Pengembangan Profesi Guru. Jakarta: PT. RajaGrafindo Persada.

Lie, Anita. 2002. Cooperatif Learning Mempraktikkan Cooperatif Learning di Ruang-Ruang Kelas. Jakarta: PT. Grasindo.

Slavin, Robert E. 2005.Cooperatif Learning Teori, Riset dan Praktik. Bandung: Nusa Media.

Sudjana, Nana. 2009. Penilaian Hasil Proses Belajar Mengajar. Bandung: PT. Remaja Rosdakarya.

Wiriaatmadja, R. 2005. Metode PTK untuk Meningkatkan Kinerja Guru dan Dosen. Bandung: Remaja Rosdakarya. 